\title{
Physical and Chemical Properties of Some European Plum Cultivars (Prunus domestica L.)
}

\author{
Mira Elena IONICA ${ }^{* *}$, Violeta NOUR ${ }^{1}$, Ion TRANDAFIR², Sina COSMULESCU ${ }^{1}$, Mihai BOTU $^{1}$ \\ ${ }^{1}$ University of Craiova, Department of Horticulture and Food Science, 13 A.I. Cuza Street, 200585, \\ Craiova,Romania; miraelena29@yahoo.com (*correspondingauthor) \\ ${ }^{2}$ University of Craiova, Department of Chemistry, 107 Calea Bucuresti Street, 200529, Craiova, Romania
}

\begin{abstract}
Fruits from twelve plum cultivars (Prunus domestica L.), were analyzed in terms of physical and chemical characteristics. The fruits trees were grown in a trial at University of Craiova - Fruit Growing Research Station (SCDP) Valcea, which is located in Bujoreni, an important Romanian plum production area. Fruits were picked at harvest maturity. Several analyzes were performed, such as fruit linear dimensions, size index, fruit weight, dry matter, soluble solids content, titratable acidity, total anthocyanins, malic, tartaric and citric acids content. The best features in terms of physical and chemical properties proved to be found in 'Alina', 'Alutus', 'Tuleu Timpuriu', 'Oltenal' and 'Renclod Althan'.
\end{abstract}

Keywords: chemical properties, cultivars, physical properties, plum

\section{Introduction}

Plums are a large and botanically diverse group of stone fruits with several named varieties being selected from over a dozen different of Prunus species. Currently, cultivated varieties are also diverse in their environmental preferences, as specific varieties have adapted to various climatic conditions throughout the entire temperate fruit-growing zones (Gomez-Plaza and Ledbetter, 2010). Plum trees can grow over the five continents of the world and production level exceeds 11 million tons (Milošević et al., 2012). Plum is a fruit crop quite spread on Earth, especially in the temperate Northern hemisphere, ranking fourth after apple, peach and pear (Visanu et al., 2012).

The common garden plum, $P$. domestica $\mathrm{L}$., is known for its diversity of fruit sizes, colors and flavors and is one of the most desirable plum species in terms of fruit quality (Gomez-Plaza and Ledbetter, 2010)

Of the 23.8 million ha representing Romanian's territory, $61.7 \%$ is represented by the agricultural acreage of the country of which $1.5 \%$ is covered by the fruit orchards and nurseries. Among the fruit species grown in our country, the European plum (P. domestica L.) is the predominant species representing a food source, and at the same time providing profits to the population (Coman et al., 2012). Regarding the cultivar, assortment has been improved numerically and qualitatitively especially with cultivars bred and named in Romania, such as: 'Centenar', 'Silvia,' 'Carpatin', 'Andreea' and 'Record'.

Due to the abundance of bioactive compounds as anthocyanins, pectins, carotenoids, plums constitute a valuable component of our diet, in terms of their nutri- tive and dietary value (Ionica et al., 2012). Also, plums are a source of vitamin A, calcium, magnesium potassium and fiber (Milošević and Milošević, 2012) and contain relatively large amounts of carbohydrates, constituting a source of available energy (Walkowiak-Tomczak, 2008). Furthermore, plums contain high amounts of antioxidant compounds (Auger et al., 2004). Also plums contain low amounts of vitamin C (Kazimierczak et al., 2006) and they represent an important source of boron.

The necessity of improving fruit quality is a priority for the modern plum culture. The changes into plum culture completed with new varieties assortments need new researches concerning the chemical composition of the fruits according with the various ecological conditions.

When growing introduced plum cultivars, it is important to determine their characteristics under local conditions such as fruit quality respectively chemical composition.

Several researches were made concerning the quality and the physical and chemical properties of plum fruits in various ecological conditions (Vitanova et al., 2004: Walkowiak-Tomczak, 2008: Vangdal et al., 2007: Usenik et al., 2009: Rop et al., 2009).

The aim of this paper is to characterize the physical and chemical properties of some plum varieties grown in the climatic conditions of Valcea County, Romania.

\section{Materials and methods}

Fruits belonging to twelve plum cultivars ( $P$. domestica L.), were analyzed in terms of physical and chemical characteristics. Fruits were picked at harvest maturity. Several 
500

analyzes were performed: dimensions, size index, average fruit weight, dry matter, soluble solids, titratable acidity, total anthocyanins, malic, tartaric and citric acids content.

Plums were grown in a trial at University of Craiova Fruit Growing Research Station (SCDP) Valcea, located in Bujoreni, an important plum production area. To mention that more then $6.4 \%$ of the Romanian plum production is located in Valcea County.

The climate is characterized by an annual average temperature over $10.2^{\circ} \mathrm{C}$, without polar cold air invasions occurring during winter. The temperatures below $-20^{\circ} \mathrm{C}$ are rare. The average annual rainfall varies from 714 to 754 $\mathrm{mm}$. Yet they are also negative characteristics such as: fragmented land and low productivity soils.

In this count almost all cultivars of temperate climate are grown, fruits having intense color and good density (Botu et al., 2012). Orchard management was consistent with cultural practice (summer pruning, fertilization with: ammonium nitrate $120 \mathrm{~kg} / \mathrm{ha}, 75 \mathrm{~kg} / \mathrm{ha}$ of $\mathrm{P}_{2} \mathrm{O}_{5}$ and $80 \mathrm{~kg} / \mathrm{ha}$ of $\mathrm{K}_{2} \mathrm{O}$, pest and disease control), without irrigation in alluvial soil with $\mathrm{pH} 6.3$.

The experiment was set up as a randomized block design in five replicates with 2 trees per cultivar. For evaluation, fruits of each cultivar from 2 trees (thirty fruits per tree) in five replicates were collected.

\section{Plant material}

Twelve plum cultivars were studied; nine of them are Romanian varieties or selections: 'Andreea': Romanian cultivar registered in 2000 by SCDP Valcea; ripening in the second half of August, medium size fruit $(45 \mathrm{~g})$ with high sugar content. 'Tuleu Timpuriu': Romanian cultivar, ripening in early August; the fruit is medium sized (35$45 \mathrm{~g}$ ), ovoid asymmetric; the skin is purple and the flesh is yellowish-green, juicy with equilibrate taste. 'Tuleu de Sinesti': local Romanian cultivar; the fruits ripen in second half of august; fruit quality is very good; the fruit is medium sized, ovoid weight $(28 \mathrm{~g})$; fruit skin is purpleblue with defined fruit bloom and the flesh is yellowishgreen, juicy with balanced taste. 'Tuleu Gras cl. 14': clonal selection of well known Romanian Tuleu gras cv.; fruits ripen in second half of August; the fruit is medium sized, ovoid, weight (32g); skin color is blue with defined fruit bloom; fruit flesh is yellowish-green, juicy, firm, balanced taste. 'Bărăgan 17': Romanian cultivar, with large fruits weight $40-50 \mathrm{~g}$, ovoid with dark blue skin; the flesh is yellowish-green used for fresh consumption and cans industry; ripen in early August. 'Renclod Althan': old plum cultivar from Central Europe; it has tasty fruits with a good flavor, weight 45-58 g, golden-yellow juicy flesh; ripening second half of August. 'Alutus': Romanian cultivar registered in 2010 by SCDP Valcea with very large fruit (74 g). 'Alina': Romanian cultivar with large fruits (45-55 $\mathrm{g}$ ), ovoid; the fruit's skin is light blue with brown shades; the flesh is yellowish-green, crispy; the fruits are ripening in first decade of August. 'Oltenal': new Romanian plum cultivar registred by SCDP Valcea; it has large fruits (51 $\mathrm{g}$ ); fruit skin color is blue-purple and covered with bloom; fruit flesh is yellowish-green. 'Flora': Romanian cultivar with large fruits (48-60 g), ovoid-round slightly flattened shape, blue skin color covered with blue-gray bloom; the flesh is greenish-white, crispy with harmonious taste. 'Reeves': cultivar from U.K.; the fruit is very large, round red-purple, with good flavor used as dessert. 'Excalibur': plum cultivar originated in U.K.; it has large fruits, with reddish-purple skin, ripening in early August.

\section{Analytical methods}

Fruit linear dimensions (length, L; width, W; thickness, T) were determined with a Luthier digital caliper manufactured by Stewart-MacDonald (USA) and the results were expressed as $\mathrm{mm}$. Average fruit weight $(\mathrm{g})$ was determined by individual weighing on an analytical scale model ABT 320-4M manufactured by Kern (Balingen, Germany). Size index was calculated using the formula: $(\mathrm{L}+\mathrm{T}+\mathrm{W}) / 3$.

The percentage of total dry matter was determined by removing water from the sample in an oven at $105^{\circ} \mathrm{C}$. Soluble solids content was measured with a digital refractometer (Hanna Instruments, Woonsocket, USA) in the juice pressed from the whole fruit, the results being expressed as percentages. The titratable acidity was determined by titration of a known amount of water extract of fruits with $0.1 \mathrm{~N} \mathrm{NaOH}$ using phenolphthalein as indicator and it was expressed as $\mathrm{g}$ malic acid/100 $\mathrm{g}$ fresh matter.

\section{Determination of total anthocyanins}

Total anthocyanins content was measured with the $\mathrm{pH}$ differential absorbance method, as described by Cheng and Breen (1991). The absorbance of the extract from $1 \mathrm{~g}$ of fruits skin, was measured at 510 and $700 \mathrm{~nm}$ in buffers at $\mathrm{pH} 1.0$ (hydrochloric acid-potassium chloride, 0.2 $\mathrm{M}$ ) and $\mathrm{pH} 4.5$ (acetate acid-sodium acetate, 1M). Anthocyanins content was calculated using a molar extinction coefficient of 29,600 (cyaniding-3-glucoside) and absorbance of $\mathrm{A}=[(\mathrm{A} 510-\mathrm{A} 700) \mathrm{pH} 1 . .0-(\mathrm{A} 510-\mathrm{A} 700) \mathrm{pH}$ 4.5]. Results were expressed as mg cyanidin-3-glucoside equivalents/100 $\mathrm{g}$ fresh weight.

\section{Determination of tartaric, malic and citric acids}

Five $\mathrm{g}$ of whole fruits were homogenized to puree in a porcelain mortar and diluted to $100 \mathrm{~mL}$ with $0.1 \mathrm{~N} \mathrm{HCl}$. After $30 \mathrm{~min}$, the extraction solution was centrifuged at $4200 \mathrm{rpm}$ for $10 \mathrm{~min}$. The supernatant was filtered through a $0.2 \mu \mathrm{m}$ pore-size filter.

Organic acid contents were determined by reversedphase HPLC on a Surveyor Thermo Electron system equipped with a Diode Array Detector (DAD) using a Hypersil Gold aQ column $(25 \mathrm{~cm} \times 4.6 \mathrm{~mm})$ with a particle size of $5 \mu \mathrm{m}$. A $50 \mathrm{mM}$ water solution of $\mathrm{KH}_{2} \mathrm{PO}_{4}$ buffer at $\mathrm{pH} 2.8$ was used as the mobile phase. The column 
Tab. 1. Physical properties of plums

\begin{tabular}{|c|c|c|c|c|c|}
\hline Cultivar & $\begin{array}{l}\text { Width (W) } \\
\text { (mm) }\end{array}$ & $\begin{array}{l}\text { Thickness }(\mathrm{T}) \\
(\mathrm{mm})\end{array}$ & $\begin{array}{l}\text { Length (L) } \\
(\mathrm{mm})\end{array}$ & Size index & $\begin{array}{l}\text { Weight } \\
(\mathrm{g})\end{array}$ \\
\hline 'Andreea' & $39.30 \pm 3.41 \mathrm{dc}$ & $37.98 \pm 3.44^{\mathrm{cd}}$ & $40.66 \pm 3.48^{b c}$ & 39.31 & $35.32 \pm 7.51^{b c}$ \\
\hline 'Tuleu Timpuriu' & $37.36 \pm 2.59^{\mathrm{cd}}$ & $35.72 \pm 2.93^{b c}$ & $43.64 \pm 1.62 \mathrm{dc}$ & 38.90 & $32.24 \pm 6.77^{\mathrm{abc}}$ \\
\hline 'Tuleu de Sineşti' & $33.95 \pm 1.83^{b}$ & $32.90 \pm 1.96^{b}$ & $42.61 \pm 2.13^{\mathrm{cd}}$ & 36.49 & $26.80 \pm 3.89^{a}$ \\
\hline 'Tuleu Gras cl. 14' & $35.20 \pm 1.41^{b c}$ & $33.46 \pm 1.07^{b}$ & $44.18 \pm 1.58 \mathrm{dc}$ & 37.62 & $29.48 \pm 2.00^{\mathrm{ab}}$ \\
\hline 'Bărăgan 17’ & $40.2 \pm 2.08 \mathrm{dc}$ & $39.32 \pm 2.03^{\mathrm{dc}}$ & $46.00 \pm 1.94^{\text {cf }}$ & 41.85 & $40.12 \pm 4.66^{\mathrm{cd}}$ \\
\hline 'Renclod Althan' & $44.18 \pm 1.68^{f}$ & $41.02 \pm 2.06^{\mathrm{cf}}$ & $39.25 \pm 1.06^{b}$ & 41.48 & $41.22 \pm 4.16^{\mathrm{cd}}$ \\
\hline 'Alutus' & $44.452 \pm 2.19^{f}$ & $43.31 \pm 2.34^{\mathrm{f}}$ & $51.68 \pm 2.22^{g}$ & 46.48 & $52.96 \pm 7.54^{\mathrm{c}}$ \\
\hline 'Alina' & $48.69 \pm 2.03^{\mathrm{g}}$ & $47.03 \pm 1.43 \mathrm{~g}$ & $57.35 \pm 3.31^{\mathrm{h}}$ & 51.02 & $71.70 \pm 8.56^{f}$ \\
\hline 'Oltenal' & $23.29 \pm 2.10^{a}$ & $22.84 \pm 2.10^{\mathrm{a}}$ & $29.21 \pm 2.00^{\mathrm{a}}$ & 25.11 & $48.20 \pm 6.27 \mathrm{dc}$ \\
\hline 'Flora' & $40.67 \pm 0.71^{\mathrm{c}}$ & $40.02 \pm 0.46^{\mathrm{dc}}$ & $39.65 \pm 0.73^{b}$ & 40.11 & $44.96 \pm 1.53^{\mathrm{de}}$ \\
\hline 'Reeves' & $52.32 \pm 3.43^{\mathrm{h}}$ & $51.368 \pm 2.90^{\mathrm{h}}$ & $47.9 \pm 1.69^{f}$ & 50.55 & $74.20 \pm 11.35^{f}$ \\
\hline 'Excalibur' & $40.29 \pm 2.41^{\mathrm{c}}$ & $39.27 \pm 2.22^{\mathrm{dc}}$ & $39.86 \pm 1.16^{b}$ & 39.80 & $68.62 \pm 8.37^{f}$ \\
\hline
\end{tabular}

${ }^{*}$ Values in the same column followed by different letters are significantly different at $\mathrm{P}<0.05$

temperature was kept at $10^{\circ} \mathrm{C}$ and the flow rate at $0.7 \mathrm{~mL}$. $\mathrm{min}^{-1}$. Detection of organic acids was at $254 \mathrm{~nm}$ and all the results were expressed in $\mathrm{mg} / 100 \mathrm{~g}$ fresh weight.

\section{Statistical analyses}

Data were evaluated by one-way analysis of variance (ANOVA) using Statgraphics Centurion XVI Software (StatPoint Technologies, Warrenton, VA, USA ). Differences in physical features and content levels among the cultivars were estimated using the least significant difference test (LSD) at $\mathrm{P}<0.05$.

\section{Results and discussions}

Varietal variation within plums cultivars results from their dimensions and weight (Tab. 1). The width ranged from $23.29 \mathrm{~mm}$ in 'Oltenal' to $52.32 \mathrm{~mm}$ in 'Reeves' with significant differences between each cultivar except the plums from 'Tuleu' group ('Tuleu Timpuriu', 'Tuleu de Sineşti,' 'Tuleu Gras cl. 14'). The same variation is shown in terms of the thickness. The plums length ranged from $29.21 \mathrm{~mm}$ in 'Oltenal' to $57.35 \mathrm{~mm}$ in 'Alina'. In terms of fruit weight there are significant differences amongst cultivars. The fruit weight ranged from $26.8 \mathrm{~g}$ in 'Tuleu de Sinești' up to $74.20 \mathrm{~g}$ in 'Reeves' values.

Also notice from the data presented that the fruits of 'Oltenal' have small size (size index 25.11) compared with Reeves (size index 50.55) and 'Alutus' (size index 46.48). The small size of 'Oltenal' fruits leads to the conclusion that this variety had problems during the season most likely due to the lack of irrigation. Beside dimensions and fruits weight the most important criteria of the consumer's acceptance of the fresh fruits are the chemical constituents that give the taste.

Significant differences of the chemical composition among the cultivars were observed (Tab. 2). The dry matter content ranged from $15.71 \%$ in 'Tuleu Timpuriu' to $25.2 \%$

Tab. 2. Chemical properties of plums

\begin{tabular}{|c|c|c|c|c|}
\hline Cultivar & $\begin{array}{c}\text { Dry matter } \\
(\%)\end{array}$ & $\begin{array}{c}\text { Soluble solids } \\
(\%)\end{array}$ & $\begin{array}{l}\text { Titratable acidity } \\
\text { (g malic acid } 100 \mathrm{~g}^{-1} \\
\text { fresh matter) }\end{array}$ & $\begin{array}{c}\text { Total anthocyanins } \\
\text { (mg cyanidin-3-glucoside } \\
\text { equivalents } / 100 \mathrm{~g} \text { fresh weight) }\end{array}$ \\
\hline 'Andreea' & $20.93 \pm 0.79^{g}$ & $14.70 \pm 0.26^{\mathrm{ab}}$ & $0.67 \pm 0.02^{c}$ & $2.59 \pm 0.099^{b}$ \\
\hline 'Tuleu Timpuriu' & $15.71 \pm 0.074^{\mathrm{bcd}}$ & $14.73 \pm 0.55^{\mathrm{ab}}$ & $0.45 \pm 0.01^{b}$ & $198.89 \pm 0.96^{j}$ \\
\hline 'Tuleu de Sinești' & $25.20 \pm 1.021^{\mathrm{i}}$ & $20.43 \pm 1.25^{c}$ & $0.73 \pm 0.038^{f}$ & $11.38 \pm 0.42^{c}$ \\
\hline 'Tuleu Gras cl. 14' & $22.59 \pm 0.66^{\mathrm{h}}$ & $17.60 \pm 0.72^{\mathrm{cd}}$ & $0.83 \pm 0.04^{h}$ & $49.87 \pm 0.98^{\mathrm{f}}$ \\
\hline 'Bărăgan 17’ & $18.12 \pm 0.18^{c}$ & $14.50 \pm 0.72^{\mathrm{ab}}$ & $0.45 \pm 0.009^{b}$ & $86.18 \pm 1.03^{h}$ \\
\hline 'Renclod Althan' & $19.00 \pm 0.51^{\mathrm{f}}$ & $15.14 \pm 1.46^{b}$ & $0.34 \pm 0.008^{a}$ & $0.41 \pm 0.00^{a}$ \\
\hline 'Alutus' & $15.63 \pm 0.39^{b c}$ & $14.46 \pm 1.15^{\mathrm{ab}}$ & $0.56 \pm 0.009^{d}$ & $121.13 \pm 1.09^{\mathrm{i}}$ \\
\hline 'Alina' & $22.55 \pm 0.19^{h}$ & $19.13 \pm 2.14^{\mathrm{de}}$ & $0.77 \pm 0.031^{\mathrm{g}}$ & $62.72 \pm 1.003^{g}$ \\
\hline 'Oltenal' & $14.75 \pm 0.20^{\mathrm{ab}}$ & $12.58 \pm 3.2^{a}$ & $0.48 \pm 0.01^{b c}$ & $10.11 \pm 0.90^{c}$ \\
\hline 'Flora' & $13.76 \pm 0.52^{a}$ & $12.40 \pm 1.21^{\mathrm{a}}$ & $0.37 \pm 0.00^{a}$ & $41.19 \pm 1.005^{\mathrm{c}}$ \\
\hline 'Reeves' & $16.99 \pm 0.33^{\mathrm{de}}$ & $15.43 \pm 0.77^{b c}$ & $0.50 \pm 0.009^{c}$ & $13.56 \pm 0.09^{d}$ \\
\hline 'Excalibur' & $16.22 \pm 0.58^{\mathrm{cde}}$ & $13.80 \pm 1.15^{\mathrm{ab}}$ & $0.50 \pm 0.009^{c}$ & $0.41 \pm 0.01^{a}$ \\
\hline
\end{tabular}

${ }^{*}$ Values in the same column followed by different letters are significantly different at $\mathrm{P}<0.05$ 
502

in 'Tuleu de Sinești'. The soluble solids content varied between $12.40 \%$ in 'Flora' and $20.43 \%$ in 'Tuleu de Sinești', values close to those presented by Vangdal et al. (2007). Plums with less than $12.5 \%$ soluble solids are unacceptable to most consumers (Vangdal, 1980). On the other hand the high value found in 'Tuleu de Sinești' show that fruits were over matured at the time of harvesting. One can also notice the high variability amongst cultivars.

The titratable acidity of plums varied between 0.34 $\mathrm{g}$ malic acid. $100 \mathrm{~g}^{-1}$ fresh matter in 'Renclod Althan' and $0.77 \mathrm{~g}$ malic acid. $100 \mathrm{~g}^{-1}$ fresh matter in 'Alina'. The acidity of fruits is given by the organic acids present in fruits especially malic, tartaric and citric acids.

Anthocyanins are some of the most important chemical constituents of plums. They give the colour of the fruits skin which can attract the consumer. The total anthocyanins content in fruits skin ranged from $0.41 \mathrm{mg}$ cyanidin3 -glucoside equivalents per $100 \mathrm{~g}$ fresh matter in 'Renclod Althan' to $198.89 \mathrm{mg}$ cyanidin-3-glucoside equivalents per $100 \mathrm{~g}$ fresh matter in 'Tuleu Timpuriu.' These high differences amongst cultivars were observed by the different colour of the fruits which varied from golden - yellow in 'Renclod Althan' until dark purple in 'Tuleu Timpuriu', values which are in accordance with the results presented by Tomas-Barberan et al. (2001).

It also shows that malic acid is the predominant acid in plums registering the highest content values amongst all cultivars (Tab. 3) to the detriment of tartaric and citric acid, values which are in line with the results presented by Usenik et al. (2008). The highest content of malic acid was found in 'Tuleu Gras cl. 14' (780.07 mg/100 g fresh matter) and the lowest values in 'Renclod Althan' (177.53 $\mathrm{mg} / 100 \mathrm{~g}$ fresh matter). Yet, the low value of malic acid content in 'Renclod Althan' plums is compensated by the tartaric acid content which recorded the highest value of all of the cultivars i.e. $175.63 \mathrm{mg} / 100 \mathrm{~g}$ fresh matter. As for the citric acid content in plums, the lowest values compared with malic and tartaric acid for all cultivars range from $10.49 \mathrm{mg} / 100 \mathrm{~g}$ fresh matter in 'Alina' to 83.80 $\mathrm{mg} / 100 \mathrm{~g}$ fresh matter in 'Oltenal'.

\section{Conclusions}

All studied plums cultivars had physical and chemical properties which make them suitable to be grown in Romania. Nevertheless, the Romanian cultivars showed a better adaptability to the climatic conditions in this region. A few cultivars might be less accepted for fresh consumption due to their low soluble solids content and high acidity. This was the case of 'Flora'. The study showed the importance of choosing the best cultivars for the consumption acceptance and profitability. The most suitable plums cultivars in terms of physical and chemical characteristics proved to be 'Alina,' 'Alutus,' 'Tuleu timpuriu,' 'Oltenal' and 'Renclod Althan'.
Tab. 3. Organic acids content of plums

\begin{tabular}{cccc}
\hline Cultivar & $\begin{array}{c}\text { Tartaric acid } \\
(\mathrm{mg} / 100 \mathrm{~g} \\
\text { fresh matter })\end{array}$ & $\begin{array}{c}\text { Malic acid } \\
(\mathrm{mg} / 100 \mathrm{~g} \\
\text { fresh matter })\end{array}$ & $\begin{array}{c}\text { Citric acid } \\
(\mathrm{mg} / 100 \mathrm{~g} \\
\text { fresh matter })\end{array}$ \\
\hline $\begin{array}{c}\text { 'Andreea' } \\
\text { 'Tuleu } \\
\text { Timpuriu' }\end{array}$ & $36.31 \pm 0.66^{\mathrm{b}}$ & $627.02 \pm 1.90^{\mathrm{i}}$ & $32.34 \pm 0.99^{\mathrm{c}}$ \\
\hline $\begin{array}{c}\text { 'Tuleu de } \\
\text { Sinești' }\end{array}$ & $97.02 \pm 0.51^{\mathrm{a}}$ & $469.52 \pm 1.40^{\mathrm{g}}$ & $52.70 \pm 1.16^{\mathrm{g}}$ \\
\hline $\begin{array}{c}\mathrm{g} \\
\text { 'Tuleu Gras } \\
\text { cl. } 14^{\prime}\end{array}$ & $363.48 \pm 1.14^{\mathrm{f}}$ & $33.93 \pm 0.91^{\text {cf }}$ \\
\hline 'Bărăgan 17' & $51.73 \pm 0.31^{\mathrm{c}}$ & $352.73 \pm 1.007^{\mathrm{d}}$ & $35.61 \pm 0.90^{\mathrm{g}}$ \\
\hline 'Renclod \\
Althan' & $175.63 \pm 0.87^{\mathrm{k}}$ & $177.53 \pm 0.80^{\mathrm{a}}$ & $26.35 \pm 0.88^{\mathrm{d}}$ \\
\hline 'Alutus' & $96.92 \pm 0.66^{\mathrm{g}}$ & $469.82 \pm 0.99^{\mathrm{g}}$ & $42.41 \pm 1.005^{\mathrm{i}}$ \\
\hline 'Alina' & $98.62 \pm 0.69^{\mathrm{h}}$ & $483.38 \pm 0.77^{\mathrm{h}}$ & $10.49 \pm 0.88^{\mathrm{a}}$ \\
\hline 'Oltenal' & $86.60 \pm 0.57^{\mathrm{f}}$ & $315.95 \pm 1.002^{\mathrm{c}}$ & $83.80 \pm 1.226^{\mathrm{k}}$ \\
\hline 'Flora' & $154.98 \pm 0.81^{\mathrm{j}}$ & $249.9 \pm 0.93^{\mathrm{b}}$ & $34.37 \pm 0.90^{\mathrm{fg}}$ \\
\hline 'Reeves' & $101.54 \pm 0.61^{\mathrm{i}}$ & $361.31 \pm 0.88^{\mathrm{c}}$ & $21.33 \pm 0.73^{\mathrm{c}}$ \\
\hline 'Excalibur' & $64.15 \pm 0.44^{\mathrm{d}}$ & $317.84 \pm 0.75^{\mathrm{c}}$ & $15.35 \pm 0.93^{\mathrm{b}}$ \\
\hline
\end{tabular}

${ }^{*}$ Values in the same column followed by different

letters are significantly different at $\mathrm{P}<0.05$

\section{References}

Auger C, Al-Awadi N, Bornet A, Rouanet JM, Gasc F, Cros G, Teissedre PL (2004). Catechins and procyanidins in Mediterranean diets. Food Res Int 37:233-245.

Coman M, Butac M, Sumedrea D, Dutu I, Iancu M, Mazilu C, Plopa C (2012). Plum culture in Romania-current status and perspectives. Acta Hort 968:25-32.

Botu M, Visanu F, Stefanescu I, Vicol A, Cernatescu M (2012). Structure of the plum cultivar assortment for region of Oltenia-Romania. Acta Hort 968:115-120.

Cheng GW, Breen PJ (1991). Activity of phenylalanine ammonialyase (PAL) and concentrations of anthocyanins and phenolics in developing strawberry fruit. J Am Soc Hortic Sci 116:865-869.

Gomez-Plaza E, Ledbetter C (2010). Handbook of fruit and vegetable flavors. In: Y.H. Hui, John Wiley \& Sons Inc.

Ionica ME, Nour V, Trandafir I (2012). The influence of aeroionized Stream on the storage capacity of plums. Acta Hort 968:205-210

Kazimierczak R, Swietlikowska K, Wasiak-Zys G (2006). Owoce krajowe (Domestic fruit). Surowce spozywcze pochodzenia roslinnego (Food raw material of plant origin). Wyd SGGW Warszawa 258-266.

Milošević T, Milošević N (2012). Factors influencing mineral composition of plum fruits. Journal of Elementology 17(3):453-464.

Milošević N, Mratinić E, Gušić SI, Milošević T (2012). Precocity yield and postharvest physical and chemical properties of plums resistant to Sharka grow in Serbian conditions. Acta 
Scientiarum Polonorum, Hortorum Cultus 11(6):23-33.

Rop O, Jurikova T, Mlcek J, Kramarova D, Sengee Z (2009). Antioxidant activity and selected nutritional values of plums (Prunus domestica L.) typical of the White Carpathian Mountains. Scientia Hort 122(4):545-549.

Tomas-Barberan FA, Gil MI, Cremin P, Waterhouse AL, HessPierce B, Kader AA (2001). HPLC-DAD-ESIMIS analysis compounds in nectarines, peaches and plums. Journal of Agric and Food Chem 49:4748-4760.

Usenik V, Kastelec D, Stampar F, Veberic R (2008). Quality changes during ripening of plums (Prunus domestica L.). Food Chem 111(4):830-836.

Usenik V, Stampar F, Veberic R (2009). Anthocyanins and fruit colour in plums (Prunus domestica L.) during ripening. Food Chem 114(2):529-534.

Vangdal E (1980). Threshold values of soluble solids in fruit determined for the fresh market. Acta Agric Scandinavica 30:445-448.
Vangdal E, Flatland S, Nordbo R (2007). Fruit quality changes during marketing of new plum cultivars (Prunus domestica L.). Hort Sci (Prague) 34:91-95.

Visanu F, Botu I, Baciu A (2012). Assessment of production of capacity for some Plum, Myrobolan and Sloe Cultivars and Selections Grown in Northern Oltenia. Acta Hort 968:7580.

Vitanova I, Dimkova S, Ivanova D (2004). Vegetative and reproductive parameters of introduced plum cultivars. Journal of Fruit and Ornamental Plant Research 12:257-262.

Walkowiak-Tomczak D (2008). Characteristics of plums as a raw material with valuable nutritive and dietary properties-a review. Pol J Food Nutr Sci 58(4):401-405. 